\title{
Viabilitas Mikrokapsul Biji Kefir Selama Penyimpanan Suhu Ruang
}

\author{
Viability of Kefir Grains Microcapsule During Storage at Room Temperature
}

\author{
D. J. Kondong', E. Taufik ${ }^{2)}$ \& I. I. Arief ${ }^{2)}$ \\ ${ }^{1)}$ Program Studi Ilmu Produksi dan Teknologi Peternakan, Sekolah Pascasarjana, Insitut Pertanian Bogor; \\ ${ }^{2}$ Divisi Teknologi Hasil Ternak, Departemen Ilmu Produksi dan Teknologi Peternakan, Fakultas Peternakan, \\ Institut Pertanian Bogor \\ E-mail corresponden author: epitaufik@apps.ipb.ac.id
}

\begin{abstract}
The process of encapsulation has done by various techniques such as the exstrusion, emulsion, spray dry, frezee dry and otherwise. The aimed of this study was to analysed the kefir grain microcapsule and its viability during storage in room temperature. The exstrusion technique was used to reach the optimum of biopolymer suspension and the percentage of kefir grains. Spray dry technique was used to produced kefir grains microcapsule before storaged in room temperature during 0,15 and 30 days. The data were analyzed by using one-way analysis of variance (ANOVA) then followed by LSM and Duncan multiple range test. The analysis results showed that the exstrusion technique has been obtained the biopolymer suspension of sodium-alginate very significantly influence $(P<0,01)$ to the yield and affected significantly $(\mathrm{P}<\mathbf{0 , 0 5})$ to the size, then the figure from microscope showed that shape of the beads were different. The results showed that the sodium-alginate was able to protect the microorganism cell by spray dry technique and so did the viability during storage in room temperature.
\end{abstract}

Keywords: extrusion technique, kefir grains, microencapculation, spray dry

\section{PENDAHULUAN}

Pengenalan masyarakat terhadap kefir pada umumnya adalah rasa asam beralkohol (Safitri dan Swarastuti 2013) dan sebagian masyarakat dapat menerima cita rasa tersebut, tetapi sebagian lagi kurang menyukainya, meskipun perbedaan rasa asam kefir tergantung dari beberapa hal. Antara lain persentase penambahan bibit kefir, suhu, lamanya waktu fermentasi dan jenis susu yang digunakan serta komposisi mikroba di dalam kefir grains yang berbeda-beda tergantung tempat asalnya (Buckle et al. 1987; Otles dan Cagindi 2003; Farnworth 2005; Irigoyen et al. 2005; Bergman et al. 2010; Febrisiantosa et al. 2013; Rosiana et al. 2013, Gul et al. 2015; Hidayat et al. 2015; Leite et al. 2015). Kefir termasuk minuman fermentasi yang berasal dari starter kefir yaitu kefir grains atau biji kefir. Biasanya biji kefir disimpan di dalam refrigerator setelah proses penyegaran yaitu memindahkan kefir grains atau biji kefir ke dalam susu segar dan selama masa penyimpanan, grains tersebut harus selalu disegarkan. Permasalahan muncul selama masa penyimpanan tersebut (seperti kekurangan nutrisi serta perubahan suhu yang tidak stabil), terutama pada masyarakat umum yang ingin membuat sendiri minuman susu fermentasi kefir, tetapi tidak mengetahui cara penyimpanan biji kefir yang baik dan benar. Hal ini yang menjadi dasar pentingnya mencoba teknik tertentu untuk mempertahankan kualitas biji kefir yaitu total populasi bakteri. Salah satu teknik yang sudah umum diketahui dan sudah banyak di lakukan adalah metode enkapsulasi.

Terdapat beberapa teknik enkapsulasi antara lain teknik ekstrusi dan emulsi (Krasaekoopt 2003; GonzalezSanchez et al. 2010) serta teknik spray dry dan frezee dry (Hamayami et al. 2001; Anal dan Singh 2007) juga teknik electrospray oleh Fukui et al. (2010). Akan tetapi teknik ekstrusi menjadi salah satu yang paling umum digunakan karena lebih mudah, biaya produksi yang rendah serta mampu menjaga kelangsungan hidup bakteri (Krasaekoopt 2003). Beberapa penelitian enkapsulasi telah mengadopsi teknik tersebut dengan menggunakan beberapa bahan pengkapsul, di mana Natrium alginat (Na-alginat) merupakan biopolimer dan polielektrolit serta termasuk salah satu bahan pengkapsul yang sering digunakan karena tidak menyebabkan toksik dan aman bagi tubuh (Krasaekoopt 2003; Chen dan Chen 2008; Adrianto 2011; Mushollaeni dan Rusdiana 2011; Yang et al. 2011; Oketič 2015; Kavoosi et al. 2018). Selain teknik ekstrusi, metode spray dry merupakan salah satu metode yang juga lebih murah dibandingkan dengan metode frezee dry. Metode ini akan menghasilkan ukuran partikel produk lebih kecil sampai ukuran $\mu \mathrm{m}$ (Walton dan Mumford 1999; Burey 2009; Rizqiati et al. 2009; Tonon et al. 2011). Oleh karena itu penggunaan kedua metode tersebut dalam suatu penelitian bisa dilakukan dengan tujuan tertentu. Penelitian ini bertujuan menganalisis mikroenkapsulasi biji kefir berdasarkan teknik ekstrusi serta mengevaluasi viabilitas biji kefir atau kefir grains hasil spray drying selama penyimpanan suhu ruang. 


\section{MATERI DAN METODE}

\section{Persiapan starter biji kefir}

Penyegaran biji kefir (koleksi Divisi Teknologi Hasil Ternak, Fapet IPB) dilakukan sebelum digunakan, dengan menambahakan 10\% (b/v) (Otles dan Cagindi 2003) ke dalam susu sapi steril, diinkubasi \pm 24 jam pada suhu $25{ }^{\circ} \mathrm{C}$. Selanjutnya disaring dengan saringan plastik, lalu dibilas dengan akuades steril. Untuk teknik ekstrusi, biji kefir tersebut kemudian dihaluskan dengan cara menggerus dan disaring dengan kain ukuran 54 mesh, ditimbang $1 \%(\mathrm{~b} / \mathrm{b})$, diinokulasi ke dalam suspensi biopolimer yang sudah disiapkan, serta di lanjutkan dengan teknik ekstrusi dan dianalisis. Untuk teknik spray drying, biji kefir yang telah disaring, dibilas, ditimbang $1 \%(\mathrm{~b} / \mathrm{b})$, ditambahkan akuades steril 1:1 dan dihaluskan dengan blender yang telah disterilkan, kemudian diinokulasi ke dalam suspensi biopolimer yang telah disiapkan dan dikeringkan dengan alat spray dryer.

\section{Mikroenkapsulasi biji kefir dengan teknik ekstrusi}

Teknik ekstrusi mengacu pada Krasaekoopt et al. (2003) dengan suspensi biopolimernya adalah Naalginat; Na-alginat:skim; Na-alginat:whey protein isolate (WPI). Sebanyak 20 gram bahan pengkapsul yang terdiri atas 2\% Na-alginat (Oketic 2015) dan 2:1 untuk bahan pengisi (filler) (Adrianto 2011) dicampur dengan akuades, dihomogenkan, kemudian disterilisasi pada suhu 121 ${ }^{0} \mathrm{C}$ selama 15 menit dan didinginkan pada suhu ruang, sedangkan WPI ditambahkan setelah suspensi biopolimer Na-alginat:WPI yang telah steril didinginkan sampai suhu $90{ }^{\circ} \mathrm{C}$, kemudian disterilisasikan lagi selama 2 menit \pm $90{ }^{\circ} \mathrm{C}$ dan didinginkan pada suhu ruang (Adrianto 2011). Suspensi biopolimer siap digunakan.

Biji kefir 1 dan 2\% (b/b) diinokulasi ke dalam Suspensi biopolimer lalu divortex, selanjutnya dipindahkan ke dalam syringe $20 \mathrm{ml}$ steril dengan ukuran jarum 23 gauge, lalu diteteskan ke dalam $60 \mathrm{ml}$ (perbandingan 1:3) larutan $\mathrm{CaCl}_{2}$ (merck) 0,1 $\mathrm{M}$ yang telah disterilkan pada jarak $\pm 2 \mathrm{~cm}$ (Oketic 2015) dengan kecepatan rotasi 200 rpm. Beads didiamkan \pm 30 menit, disaring dan dibilas dengan larutan $\mathrm{NaCl}$ (merck) $0,85 \%$ steril, ditiriskan \pm 2 menit, kemudian dianalisis.

\section{Pengeringan kering (spray drying)}

Suspensi biopolimer-sel terbaik berdasarkan teknik ekstrusi dipilih, selanjutnya diproduksi dengan alat spray dryer (GEA Nira A/S, Denmark) dengan suhu inlet $160{ }^{\circ} \mathrm{C}$ dan outlet $65{ }^{\circ} \mathrm{C}$ (Crittenden 2006; Ying et al. 2010).

\section{Penyimpanan mikrokapsul biji kefir atau kefir grain (MKG)}

Mikrokapsul biji kefir (MKG) hasil spray drying selanjutnya disimpan pada suhu ruang $\left( \pm 29{ }^{\circ} \mathrm{C}\right.$; RH 50 \%) selama 0, 15 dan 30 hari setelah dimasukkan ke dalam plastik Low Density Polyetilen (LDPE) steril dan dizip dengan zipper hot sehingga tetap steril (Metanggui 2002).

\section{Peubah yang Diamati}

Peubah yang diamati meliputi rendemen (\%), ukuran beads $(\mathrm{mm})$ dengan jangka sorong digital (Mitutoyo CD8 "CSX, Japan) dan pengamatan mikroskop (Optica) untuk bentuk beads MKG pada perbesaran 4x10 (Nguyen et al. 2015), total bakteri asam laktat (BAL) dan kapang khamir (KK) (Maturin dan Peeler 1998; Tournas et al. 1998).
Analisis Data

Rancangan yang digunakan pada penelitian tahap ekstrusi adalah Rancangan Acak Kelompok (RAK) pola faktorial dengan $3 \times 2$ perlakuan yaitu perbedaan bahan pengkapsul dan persentase penambahan kefir grain, sedangkan penyimpanan mikrokapsul biji kefir mengacu pada pola Rancangan Acak Lengkap (RAL) dengan 3 perlakuan yaitu waktu penyimpanan 0, 15 dan 30 hari (Mattjiik dan Sumertajaya 2013). Semua perlakuan diulang tiga kali. Data diolah dengan analisis ragam (ANOVA) serta uji lanjut dengan LSMeans dan rata-rata perbandingan Duncan untuk mengevaluasi data yang didapat dengan SAS 9,1 .

\section{HASIL DAN PEMBAHASAN}

\section{Rendemen, Ukuran dan Bentuk Beads Mikrokapsul Kefir Grain atau Biji Kefir Biji Kefir (MKG)}

Berdasarkan teknik ekstrusi, Na-alginat dengan $1 \%$ penambahan biji kefir adalah suspensi biopolimersel yang terbaik. Hasil analisis varian menunjukan adanya interaksi antara media suspensi biopolimer dan persentase penambahan biji kefir pada peubah rendemen yaitu Na-alginat, sedangkan kedua perlakuan suspensi biopolimer Na-alginat:skim dan Na-alginat:WPI dengan penambahan biji kefir 1 dan $2 \%$ tidak menunjukan pengaruh. Sementara itu peubah ukuran tidak menunjukan adanya interaksi antara media suspensi biopolimer dan persentase penambahan biji kefir. Hasil uji lanjut LSMeans menunjukan sangat beda nyata $(\mathrm{P}<0,01)$ untuk perlakuan suspensi biopolimer $\mathrm{Na}$-alginat dan persentase penambahan biji kefir terhadap rendemen, sedangkan peubah ukuran terbukti berbeda nyata $(\mathrm{P}<0,05)$ pada perlakuan suspensi biopolimer Na-alginat (Tabel 1).

Suspensi biopolimer Na-alginat yang berbeda diduga disebabkan oleh perbedaan bobot molekul dibandingkan dengan bahan pengisi (filler) skim dan WPI serta bobot biji kefir. Menurut Yang et al. (2007), Mushollaeni dan Rusdiana (2011) serta Rahmani dan Sheardown (2018) bahwa, pada umumnya berat molekul Na-alginat sekitar 79000 sampai $200000 \mathrm{~g} \mathrm{~mol}^{-1}$, sementara itu Subaryono (2010) menyatakan bahwa alginat memiliki berat molekul 32 sampai $200 \mathrm{kDa}$.

Hasil ini sama dengan penelitian Adrianto (2011) dimana rendemen dan ukuran terbukti berbeda nyata untuk suspensi biopolimer Na-alginat, dan suspensi biopolimer Na-alginat: whey protein concentrate (WPC) terbukti memiliki rendemen paling kecil bila dibandingkan dengan rendemen suspensi biopolimer Na-alginat:whey protein isolate (WPI) pada penelitian ini. Hal ini mengindikasikan bahwa WPI memiliki bobot molekul yang lebih besar dibandingkan dengan WPC. Berdasarkan hasil uji lanjut nilai rata-rata ukuran beads mikrokapsul biji kefir berkisar antara 2,32 dan 2,62 mm, di samping itu suspensi bipolimer-sel Na-alginat terbukti berbeda nyata $(\mathrm{P}<0,05)$ dengan Na-alginat:skim dan Na-alginat:WPI. Pebedaan ukuran beads tersebut dipengaruhi oleh viskositas serta ukuran jarum (needle) yang digunakan. Viskositas larutan akan menghasilkan ukuran yang berbeda pada kecepatan yang sama, dan rata-rata diameter beads mencapai maksimal pada konsentrasi alginat 3\% (Sheu dan Marshall 1993). Penelitian ini menghasilkan rata-rata ukuran beads 
Kondong et al.

Jurnal Ilmu Produksi dan Teknologi Hasil Peternakan 5 (2): 65-70

Tabel 1. Rendemen, ukuran dan bentuk beads mikrokapsul biji kefir berdasarkan teknik ekstrusi

\begin{tabular}{|c|c|c|c|c|c|}
\hline \multirow[t]{2}{*}{ Peubah } & \multirow{2}{*}{$\begin{array}{c}\text { Penambahan biji kefir } \\
(\%)\end{array}$} & \multicolumn{3}{|c|}{ Suspensi } & \multirow[t]{2}{*}{ Rata-rata } \\
\hline & & Na-alginat & Na- alginat:skim & Na-alginat: WPI & \\
\hline \multirow[t]{3}{*}{ Rendemen (\%) } & 1 & $69,98 \pm 7,46 a$ & $59,70 \pm 3,48 \mathrm{c}$ & $62,00 \pm 5,38 \mathrm{bc}$ & $63,89 \pm 6,78$ \\
\hline & 2 & $66,10 \pm 5,41 b$ & $62,43 \pm 3,33 c$ & $62,50 \pm 3,38 b c$ & $63,68 \pm 4,03$ \\
\hline & Rata-rata & $68,04 \pm 6,20 \mathrm{a}^{*}$ & $61,06 \pm 3,39 b^{*}$ & $62,25 \pm 4,02 \mathrm{~b}^{*}$ & \\
\hline \multirow[t]{3}{*}{ Ukuran (mm) } & 1 & $2,62 \pm 0,04$ & $2,41 \pm 0,13$ & $2,42 \pm 0,12$ & $2,48 \pm 0,13$ \\
\hline & 2 & $2,56 \pm 0,07$ & $2,32 \pm 0,05$ & $2,46 \pm 0,20$ & $2,45 \pm 0,15$ \\
\hline & Rata-rata & $2,59 \pm 0,06 \mathrm{a}$ & $2,37 \pm 0,09 b$ & $2,44 \pm 0,15 b$ & \\
\hline \multirow[t]{2}{*}{ Bentuk } & 1 & Bulat bola & Bulat telur & Bulat telur & \\
\hline & 2 & Bulat bola & Bulat telur & Bulat telur & \\
\hline
\end{tabular}

Keterangan: Huruf berbeda pada baris yang sama menunjukkan beda nyata $(\mathrm{P}<0,05)$; sangat beda nyata $(\mathrm{P}<0,01)$

yang termasuk ke dalam kategori teknik ekstrusi, karena berdasarkan review Krasaekoopt et al. (2003) ukuran mikrokapsul beads berdasarkan teknik ekstrusi sekitar 2 sampai $5 \mathrm{~mm}$. Sedangkan hasil enkapsulasi hydrogel yang diperoleh oleh (Nguyen et al. 2015) untuk rata-rata ukuran partikel adalah 340 sampai $520 \mu \mathrm{m}$ dengan diameter inner nozzle 30 gauge. Hal ini disebabkan oleh perbedaan ukuran (Gauge) needle yang digunakan, jarak tetesan serta jenis bahan pengkapsul dan bahan inti yang digunakan. Menurut Gbassi dan Vandamme (2012), pada umumnya diameter jarum dan viskositas larutan akan mempengaruhi ukuran dan bentuk beads.

Menurut Sheu dan Marshall (1993) beads dengan bentuk bulat bola dihasilkan dari larutan yang lebih kental. Hal ini terbukti pada suspensi biopolimer Na-alginat tanpa filler yang membentuk beads mikrokapsul dengan sempurna yaitu bulat bola dan menjadi bentuk beads yang terbaik. Hal tersebut sebabkan oleh viskositas yang lebih tinggi (Tabel 1, Gambar $1 \mathrm{a}, \mathrm{b}$ dan 2). Perbedaan viskositas dari suspensi biopolimer menjadi alasan yang menyebabkan perubahan bentuk beads. Menurut Kavoosi et al. (2018) alginat memiliki kapasitas pembentuk gel yang sangat baik. Sejalan dengan Adrianto (2011) yang membuktikan bahwa penambahan filler tidak mempengaruhi bentuk beads dan bentuk beads terbaik adalah bentuk bulat bola.

Berdasarkan Gambar 2, viskositas Na-alginat tanpa filler yang dibandingkan dengan suspensi biopolimer dan penambahan filler 2:1 (skim, WPI) terbukti berbeda nyata $(\mathrm{P}<0,01)$. Perbedaan tersebut disebabkan bahan filler yaitu WPC dan WPI tidak memiliki sifat hidrokoloid alami, sehingga menurunkan nilai kekentalan larutan. Nilai viskositas suspensi biopolimer Na-alginat (2\%) pada penelitian ini lebih rendah dari waktu dekantasi yang paling optimum oleh Subaryono dan Apriani (2010) yaitu 419 dan $746 \mathrm{cP}$ (1\% natrium alginat). Akan tetapi rata-rata nilai viskositas tersebut lebih tinggi dibandingkan dengan penelitian Mushollaeni dan Rusdiana (2011) dengan viskositas terendah sampai tertinggi adalah 25, 38 dan 39 cps (1\% natrium alginat), dan penelitian Adrianto (2011) yaitu $81 \mathrm{cP}$ ( $2 \%$ natrium alginat). Menurut Subaryono (2010), berat molekul dan keberadaan ion dalam larutan akan mempengaruhi viskositas larutan alginat, di mana larutan alginat akan menjadi rendah bila dalam kondisi
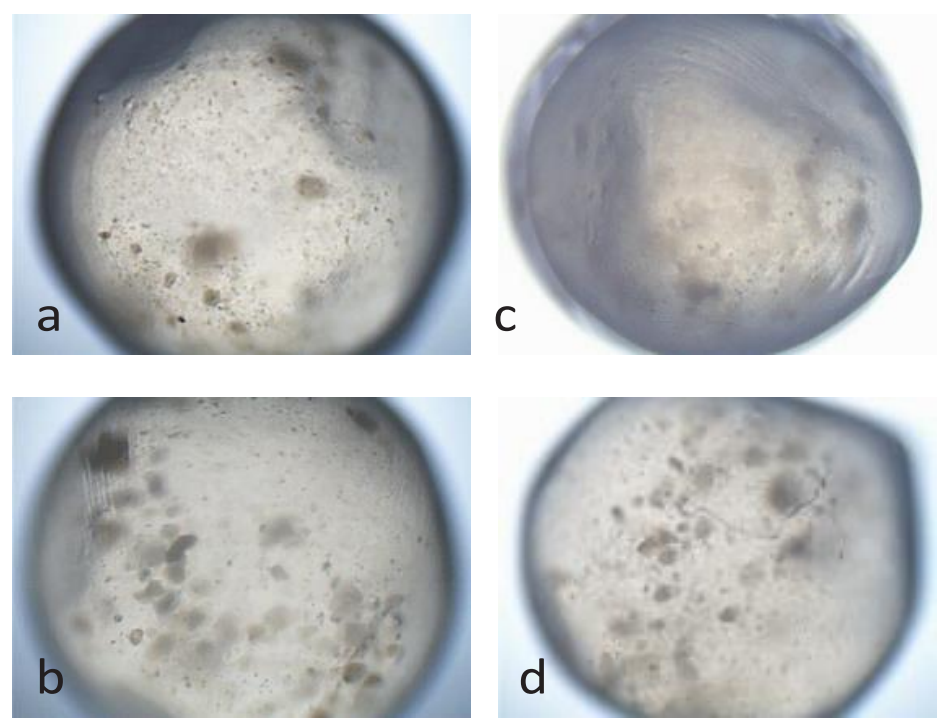

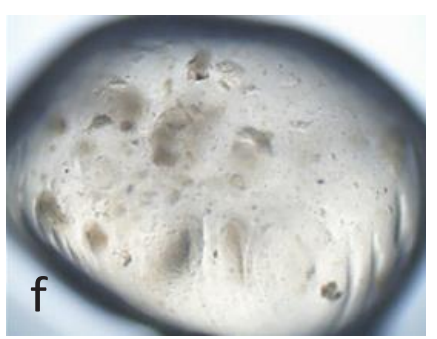

Gambar 1. Beads mikrokapsul biji kefir (Perbesaran 4X10). KG: kefir grain; a) Na-alginat 1\% KG; b) Na-alginat 2\% KG; c) Na-alginat:skim 1\% KG; d) Na-alginat:skim 2\% KG; e) Na-alginat:WPI 1\% KG; f) Na-alginat:WPI 2\% KG 


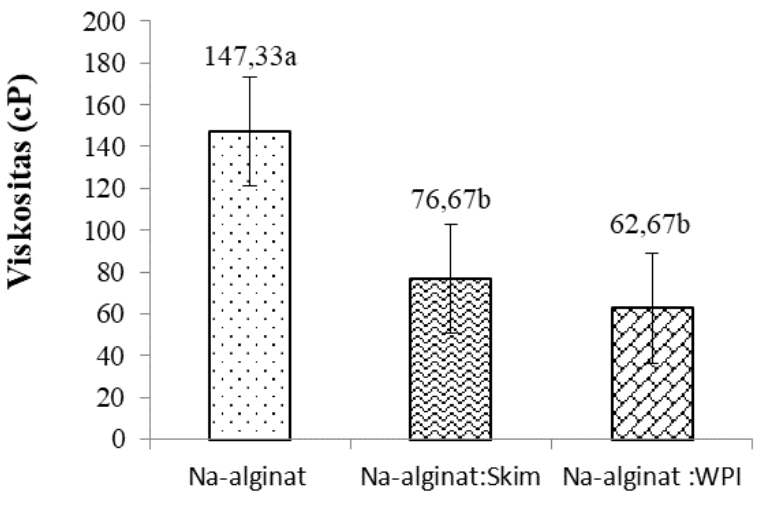

Suspensi Bio-polimer

Gambar 2. Viskositas suspensi biopolimer. Huruf di sebelah angka menunjukan pembandingan nilai tengah pada tiap perlakuan berdasarkan uji beda nyata terkecil pada taraf nyata 0,01 ; garis tegak pada kurva menunjukan galat baku

tanpa kation bervalensi dua atau tiga, serta adanya bahan pengkelat.

\section{Penyimpanan Mikrokapsul Kefir Grain atau Biji Kefir (MKG)}

Berdasarkan hasil uji lanjut Duncan (Gambar 3) selama masa penyimpanan mikrokapsul kefir grain atau biji kefir (MKG) hasil spray drying, jumlah bakteri asam laktat (BAL) dan kapang khamir (KK) menunjukan fluktuatif yang sangat berbeda nyata $(\mathrm{P}<0,01)$. Perubahan tersebut terlihat jelas pada jumlah BAL yang berfluktuatif setelah hari ke 0 . BAL mengalami penurunan pada hari ke 15 kemudian meningkat lagi pada hari ke 30, sedangkan jumlah KK mengalami peningkatan berturut-turut sejak hari ke 0 kemudian naik perlahan-lahan sampai hari ke 30. Perubahan pada jumlah BAL disebabkan oleh tahapan atau masa penyesuaian diri di awal hari penyimpanan pada kondisi suhu ruang, kemudian setelah mampu bertahan dan menyesuaikan diri dengan suhu lingkungan (suhu ruang), BAL memasuki tahap logaritmik pada hari-hari berikutnya (hari ke 15 dan 30). Berbeda dengan KK yang terbukti mampu mempertahankan diri pada suhu ruang dan sudah memasuki tahap logaritmik setelah hari ke 0 sampai hari ke 30. Hal ini sesuai dengan pendapat Tucker dan Featherstone (2011) bahwa, pada dikondisi gula tinggi dengan $\mathrm{a}_{\mathrm{w}}$ rendah $(<0,6)$ khamir mampu mempertahankan diri untuk terus hidup.

Pertumbuhan BAL dan KK pada hari ke 30, menunjukan perbedaan pada total populasi akhir. Pertumbuhan KK terbukti lebih rendah 0,18 Log CFU g ${ }^{-1}$ dibandingkan dengan populasi BAL. Perbedaan ini diduga karena KK mulai memasuki fase stagnan berdasarkan kurva pertumbuhan mikroba, sebaliknya BAL diduga masih mengalami fase logaritmik. Perubahan populasi BAL dan KK yang mampu memasuki tahapan membelah diri pada masa penyimpanan (terlebih pada KK) diduga

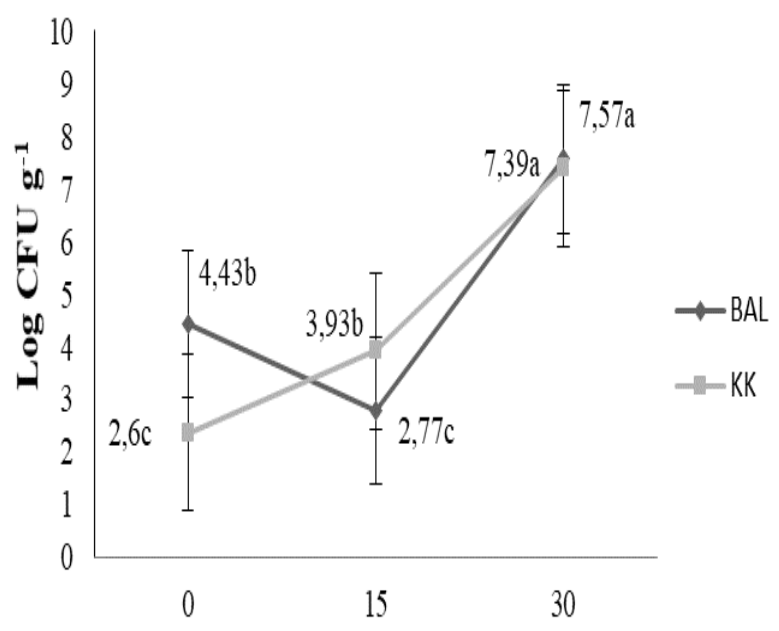

Penyimpanan suhu ruang (Hari)

Gambar 3. Total bakteri asam laktat (BAL) dan kapang khamir (KK) MKG selama penyimpanan suhu ruang. Angka di sebelah kiriø:KK; angka di sebelah kanan $\diamond: B A L ;$ huruf di sebelah angka menunjukan pembandingan nilai tengah pada tiap perlakuan berdasarkan uji beda nyata terkecil pada taraf nyata 0,01 ; garis tegak pada kurva menunjukan galat baku.

disebabkan oleh adanya Na-alginat yang digunakan sebagai nutrisi untuk pertumbuhan sel mikroorganisme tersebut. Hal ini dikarenakan hanya Na-alginat yang terdapat pada MKG yang adalah bahan pengkapsul selain kefiran dalam grain yang merupakan polisakarida (Irigoyen et al. 2005), artinya tidak ada faktor lain yang dapat mempengaruhi pertumbuhan sel bakteri tersebut. Naalginat sebagai bahan pengkapsul, merupakan karbohidrat dan termasuk ke dalam kelompok struktur yang kompleks yaitu polisakarida. Struktur kimia dari Na-alginat adalah 1,4'-linked $\beta$-D-mannuronic acid dan $\alpha$-L-guluronic acid residues (Gombots dan Wee 2012). Menurut Subaryono (2010), hanya alginat oligosakarida (AOS) yang dapat digunakan sebagai prebiotik. Akan tetapi pada penelitian ini natrium alginat terbukti dapat mempengaruhi pertumbuhan BAL dan KK selama penyimpanan suhu ruang. Hal tersebut diduga disebabkan adanya interaksi antara bakteri asam laktat, bakteri asam asetat, kapang dan khamir, yang secara enzimatis berperan dalam perubahan sifat kimiawi natrium alginat.

Pertumbuhan BAL dan KK hasil spray drying pada penelitian ini menunjukan bahwa metode tersebut dapat digunakan untuk proses produksi mikrokapsul terhadap mikroorganisme tertentu, dengan memperhatikan suhu (Burey 2009; Rizqiati et al. 2009) serta konsentrasi larutan yang akan digunakan (Phisut 2012).

Menurut Dianawati et al. (2013) strain L. acidophilus dan L. cremoris memiliki ketahanan lebih tinggi berdasarkan hasil teknik spray drying dibandingkan dengan teknik freeze drying pada suhu ruang $\left(25{ }^{\circ} \mathrm{C}\right)$ dengan $\mathrm{a}_{\mathrm{w}}$ rendah, akan tetapi kedua bakteri tersebut terbukti tidak mengalami perubahan pada penyimpanan 4 
minggu pertama. Berbeda dengan jenis bakteri asam laktat (BAL) pada penelitian ini yang terbukti mengalami fase pertumbuhan setelah hari ke 15 hingga mencapai 7,57 Log CFU g ${ }^{-1}$, meskipun strainnya tidak diketahui dengan jelas. Ying et al. (2010) juga membuktikan bahwa viabilitas spray-dried LGG microcapsules (SDMC) lebih stabil dibandingkan dengan freeze-dried $L G G$ microcapsules (FDMC) pada penyimpanan suhu ruang $\left(25^{\circ} \mathrm{C}\right)$ dengan $\mathrm{a}_{\mathrm{w}}$ yang tinggi. Sejalan dengan penelitian ini yang menunjukan viabilitas BAL dan KK terhadap pengaruh suhu ekstrim selama proses pengeringan dengan alat spray dryer, dan selama penyimpanan suhu ruang.

\section{KESIMPULAN}

Suspensi biopolimer-sel terbaik adalah Na-alginat tanpa filler dengan penambahan $1 \%$ biji kefir berdasarkan teknik ekstrusi. Na-alginat sebagai bahan pengkapsul terbukti mampu melindungi starter biji kefir terhadap suhu ekstrim selama proses spray dry dan selama penyimpanan suhu ruang.

\section{DAFTAR PUSTAKA}

Adrianto A. 2011. Enkapsulasi Lactobacillus casei dengan teknik ekstrusi sebagai stater pembuatan dadih susu sapi. Skripsi. Institut Pertanian Bogor. Bogor.

Anal AK, Singh H.2007. Review. Recent advances in Microencapsulation of probiotics for Industrial applications and targeted delivery. Trends in Food Science \& Technology, 18:240-251. doi:10.1016/j. tifs.2007.01.004

Assadi MM, Pourahmad R, Moazami N. 2000. Use of isolated kefir starter cultures in kefir production. World Journal of Microbiology \& Biotechnology, 16:541-543. doi:https://doi.org/10.1023/A:1008939132685

Bergmann RSdeO, pereira MA, veiga SMOM, schneedorf JM, oliveira NdeMS, fiorini JE. 2010. Microbial profile of a kefir sample preparations-grains in natura and lyophilized and fermented suspension. Ciênc. Tecnol. Aliment., Campinas, 30(4): 1022-1026.

Buckle KA, Edwards RA, Fleet GH, Wootton M. 1985. Ilmu pangan. Cet-2007. Penerjemah: Purnomo H, Adiono. Jakarta (ID). UI Press. Judul asli : Food science

Burey P, Bhandari BR, Howes T, Gidley MJ. 2009. Gel particles from spray-dried disordered polysaccharides. Carbohydrate Polymers, 76:206-213. doi:10.1016/j. carbpol.2008.10.001

Chen HC, Wang SY, Chen MJ. 2008. Microbiological study of lactic acid bacteria in kefir grains by culture-dependent and culture-independent methods. Food Microbiology, 25:492-501. doi:10.1016/j. fm.2008.01.003

Crittenden R, Weerakkody R, Sanguansri L, Augustin MA. 2006. Synbiotic microcapsules that enhance microbial viability during nonrefrigerated storage and gastrointestinal transit. Appl. Environ. Microbiol, 72(3):2280-2282. doi:10.1128/AEM.72.3.22802282.2006

Dianawati D, Mishra V, Shah NP. 2013. Stability of microencapsulated Lactobacillus acidophilus and Lactococcus lactis ssp. cremoris during storage at room temperature at low aw. Food Research International, 50:259-265. doi:org/10.1016/j.foodres.2012.10.023

Farnworth ER. 2005. Kefir - a complex probiotic. Food Science and Technology, Bull:Functional Foods, 2(1)1-17.doi:10.1616/1476-2137.13938. IFIS Pub

Febrisiantosa A, Purwanto BP, Arief II, Widyastuti Y. 2013. Karakteristik fisik, kimia, mikrobiologi whey kefir dan aktivitasnya terhadap penghambatan angiotensin converting enzyme (ACE). J. Teknol. dan Industri Pangan, 24(2). doi:10.6066/jtip.2013.242147

Fukui Y, Maruyama T, Iwamatsu Y, Fujii A, Tanaka T, Ohmukai Y, Matsuyama H. 2010. Preparation of monodispersed polyelectrolyte microcapsules with high encapsulation efficiency by an electrospray technique. Colloids and Surfaces A: Physicochem. Eng. Aspects, 370:28-34. doi:10.1016/j.colsurfa.2010.08.039

Gbassi GK, Vandamme T. 2012. Probiotic encapsulation technology: from microencapsulation to release into the gut. Pharmaceutics, 4:149-163. doi:10.3390/ pharmaceutics4010149

Gonzalez-Sanchez F, Azaola A, Gutierrez-Lopez GF, Hernandez-Sanchez H. 2010. Viability of microencapsulated Bifidobacterium animalis ssp. lactis BB12 in kefir during refrigerated storage. International Journal of Dairy Technology, 63(3). doi:10.1111/ j.1471-0307.2010.00604.x

Gul O, Mortas M, Atalar I, Dervisoglu M, Kahyaoglu T. 2015. Manufacture and characterization of kefir made from cow and buffalo milk, using kefir grain and starter culture. J. Dairy Sci., 98 :1517-1525. doi:http://dx.doi. org/10.3168/jds.2014-8755

Gombotz WR, Wee SF. 2012. Protein release from alginate matrices. Advanced Drug Delivery Reviews, 64:194 205. doi:http://dx.doi.org/10.1016/j.addr.2012.09.007

Hamayami E, Ngatirah, Rahayu ES, Utami T. 2001. Ketahanan dan viabilitas probiotik bakteri asam laktat selama proses pembuatan kultur kering dengan metode freeze dan spray drying. Jurnal Teknol. dan Industri Pangan, 12(2).

Hidayat E, Kinayungan IW, Irhas M, Sidiq F, Susanti R. 2015. Analysis of proximate and protein profile of kefir from fermented goat and cow milk. Biosaintifika, 7(2).

Irigoyen A, Arana I, Castiella M, Torre P, Ibanez FC. 2005. Microbiological, physicochemical, and sensory characteristics of kefir during storage. Food Chemistry, 90:613-620. doi:10.1016/j.foodchem.2004.04.021

Irigoyen A, Ortigosa M, Garcia S, ibanez FC, Torre P. 2012. Comparison of free amino acids and volatile components in three fermented milks. International Journal of Dairy Technology, 65. doi:10.1111/j.14710307.2012.00855.x

Kavoosi G, Derakhshan M, Salehi M, Rahmati L. 2018. Microencapsulation of Zataria essential oil in agar, alginate and carrageenan. Innovative Food Science and Emerging Technologies, 45:418-425. doi:https://doi. org/10.1016/j.ifset.2017.12.010

Krasaekoopt W, Bhandari B, Deeth H. 2003. Evaluation 
of encapsulation techniques of probiotics for yoghurt. International Dairy Journa, 13:3-13. PII:S09586946(02)00155-3

Leite AMO, Miguel MAL, Peixoto RS, Ruas-Madiedo P, Paschoalin V MF, Mayo B, Delgado S. 2015. Probiotic potential of selected lactic acid bacteria strains isolated from Brazilian kefir grains. Journal of Dairy Science, 98(6). doi:http://dx.doi.org/10.3168/jds.2014-9265

Mattjik AA, Sumertajaya M. 2013. Perancangan percobaan dengan aplikasi SAS dan Minitab. Jilid 1. Bogor (ID). IPB Press.

Maturin LJ, Peeler JT. 1998. Bacteriological Analytical Manual (BAM). 8th Edition, Revision A. Chapter 3. Revised: 2000-APR-17.

Metanggui AS. 2002. Pengaruh jenis kemasan Low Density Polythylene (LDPE) dan botol gelas terhadap karakter starter kefir kering beku. Skripsi. Bogor (ID). Institut Pertanian Bogor.

Mushollaeni W, Rusdiana E. 2011. Karakterisasi natrium alginat dari Sargassum sp., Turbinaria sp. dan Padina sp. J. Teknol. dan Industri Pang, 22 (1).

Nguyen DK, Son YM, Lee NE. 2015. Hydrogel Encapsulation of Cells in Core-Shell Microcapsules for Cell Delivery. Adv Healthcare Mater, 4:1537-1544. doi:10.1002/adhm.201500133

Oketic K, Matijasic BB, Obermajer T, Radulovic Z, Levic S, Mirković N, Nedovic V. 2015. Evaluation of propidium monoazide real-time PCR for enumeration of probiotic lactobacilli microencapsulated in calcium alginate beads. Beneficial Microbes, 6(4):573-581. doi:10.3920/BM2014.0095

Otles S, Cagindi O. 2003. Kefir: a probiotic dairycomposition, nutritional and therapeutic aspects. Pakistan Journal of Nutrition, 2(2):54-59.

Phisut N. 2012. MiniReview: Spray drying technique of fruit juice powder: some factors influencing the properties of product. IFRJ, 19(4):1297-1306.

Rizqiati H, Jenie BSL, Nurhidayat N, Nurwitri CC. 2009. Karakteristik mikrokapsul probiotik Lactobacillus Plantarum yang dienkapsulasi dengan susu skim dan gum arab. J. Indon. Trop. Anim. Agric. 34(2).

Rosiana E, Nurliana, Armansyah TTR. 2013. Kadar asam laktat dan derajat asam kefir susu kambing yang di fermentasi dengan penambahan gula dan lama inkubasi yang berbeda. Jurnal Medika Veterinaria, 7(2).
Safitri MF, Swarastuti A. 2013. Kualitas kefir berdasarkan konsentrasi kefir grain. Jurnal Aplikasi Teknologi Pangan, 2(2).

Sheu TY, Marshall RT. 1993. Microentrapment of Lactobacilli in calcium alginate gels. Journal of Food Science, 54(3).

Subaryono, Apriani SNK. 2010. Pengaruh dekantasi filtrat pada proses ekstraksi alginat dari Sargassum $s p$. terhadap mutu produk yang dihasilkan. Jurnal Pascapanen dan Bioteknologi Kelautan dan Perikanan, 5(2). doi: http://dx.doi.org/10.15578/jpbkp.v5i2.420

Subaryono. 2010. Modifikasi alginat dan pemanfaatan produknya. Squalen, 5(1).

Tonon RV, Brabet C, Hubinger MD. 2011. Spray drying of Acai (Euterpe oleracea Mart) juice: effect of process variables and type of carrier agent on product's quality and stability. New York (US). Nova Science publisher, Inc.

Tournas V, Stack ME, Mislivec PB, Koch HA, Bandler R. 1998. Bacteriological Analytical Manual (BAM). 8th Edition, Revision A, Chapter 18. Revised: 2000-APR17.

Tucke G, Featherstone S. 2011. Essential of thermal processing. Blackwell Pub Ltd.

Walton DE, Mumford CJ. 1999. Spray dried products characterization of particle morphology. Trans IChemE, 77(Part A).

Ying DY, Phoon MC, Sanguansri L, Weerakkody R, Burgar I, Augustin MA. 2010. Microencapsulated Lactobacillus rhamnosus GG powders: relationship of powder physical properties to probiotic survival during storage. Journal of Food Science, 75(9). doi:10.1111/ j.1750-3841.2010.01838.X

Yang JS, Xie YJ, He W. 2011. Research progress on chemical modification of alginate: A review. Carbohydrate Polymers, 84:33-39. doi:10.1016/j. carbpol.2010.11.048

Yang L, Zhang B, Wen L, Liang Q, Zhang LM. 2007. Amphiphilic cholesteryl grafted sodium alginate derivative: Synthesis and self-assembly in aqueous solution. Carbohydrate Polymers, 68:218-225. doi:10.1016/j.carbpol.2006.12.020 